\title{
SLURRY TRENCH
}

\section{Yu-Chao Li}

College of Civil Engineering and Architecture, Zhejiang University, China

Peter John Cleall

School of Engineering, Cardiff University, UK

\section{Definition}

A slurry trench is a long narrow vertical excavation, progressively filled with slurry as it is excavated, typically used in the construction of diaphragm walls in civil engineering or cut-off walls (vertical barriers) for inhibition of groundwater flow or containment of contaminant transport.

\section{Construction}

Slurry trench construction is often started with a set of guide walls, which are constructed on the ground surface to outline the desired slurry trench and guide the excavation machinery. The slurry, regularly a thick colloidal mixture of bentonite (an absorbent aluminum phyllosilicate clay consisting mostly of montmorillonite) and water, typically consisting of 5\% solid and $95 \%$ water by weight, is mixed for hydration before emplacement. Trenches shallower than $25 \mathrm{~m}$ can be excavated using a backhoe while deeper trenches are usually excavated by a clamshell or dragline. The typical procedure of excavation of slurry trenches by a clamshell is illustrated in Fig 1. With either method, to prevent trench collapse during excavation, the trench is always fully filled with slurry so that it exerts pressure on the trench walls to balance the earth pressure and hydraulic pressure from the surrounding soils. The slurry also penetrates in the surrounding soil and forms a low-permeability "filter cake" on the trench side wall that contributes to the low permeability of the completed walls. Once a suitable length of slurry trench is excavated, backfill materials, such as reinforced concrete, plastic concrete, soil-bentonite and cement-bentonite, are placed into the trench to form diaphragm walls or cut-off walls by displacing the less-dense slurry. Diaphragm walls are often used as a structural system in civil engineering either for temporary excavation support or as part of permanent structure. Cut-off walls are commonly used to control groundwater flow or contain subsurface contamination. The excess displaced slurry is usually pumped out, filtered, and stored in tanks for reuse in a new trench or recycled. For cut-off walls, in most cases the excavated slurry trench is extended $60 \mathrm{~cm}$ to $90 \mathrm{~cm}$ into a low permeability stratum such as clay or bedrock to provide a key to assure minimal leakage under the final wall; although in some cases "hanging" slurry trenches, which penetrate the groundwater table, are used to stop the movement of floating contaminants or gases. Slurries fabricated with biodegradable polymers, instead of bentonite, may be used in slurry trenches for specific applications such as drainage trenches and permeable reactive barriers.

Slurry Trench, Fig. 1 Typical procedure of excavation of slurry trenches by a clamshell: (a) the first panel is excavated with slurry filling the excavated space simultaneously; (b) the second panel is excavated to form a continuous slurry trench. 

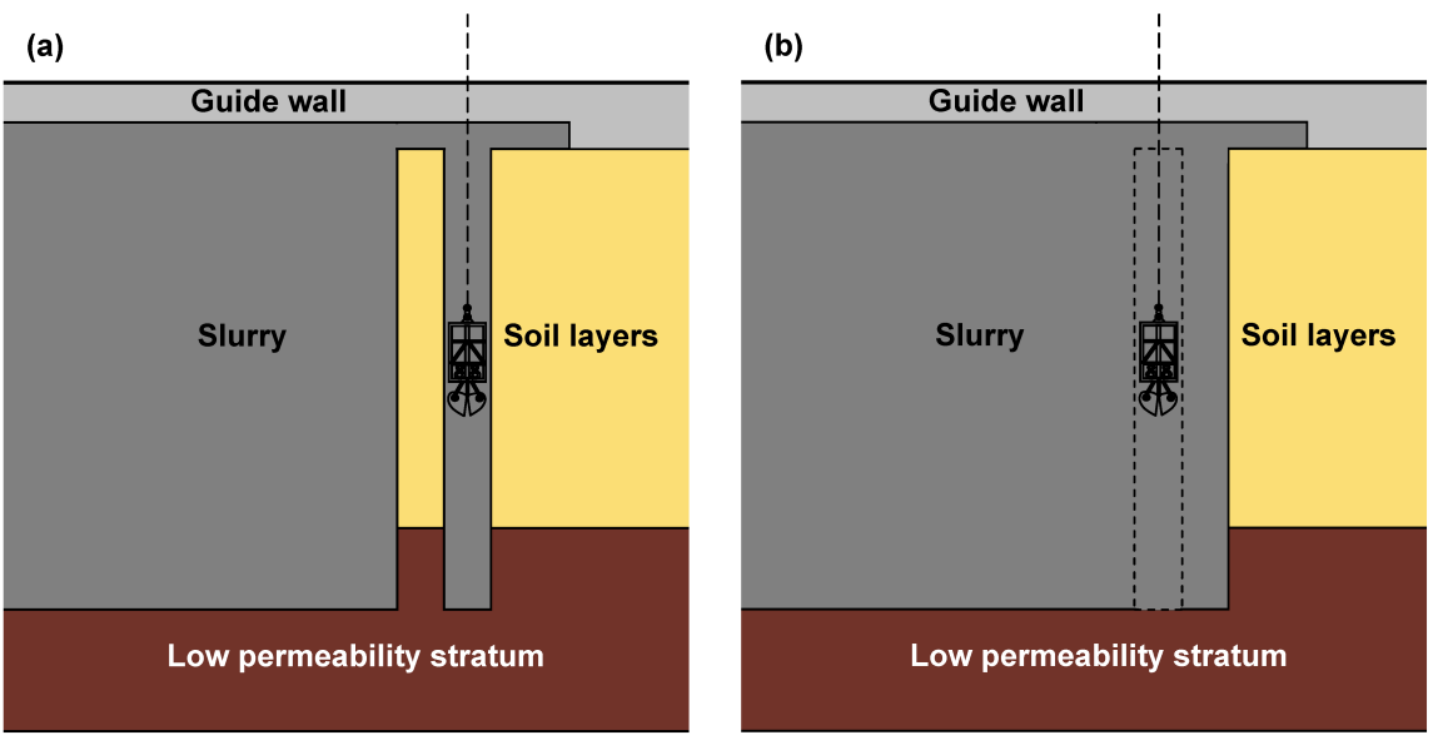